\title{
MEASUREMENTS TO DETERMINE EXTINC- TION COEFFICIENTS AND TEMPERATURE GRADIENTS IN THE NORTH SEA AND ENGLISH CHANNEL
}

\author{
By M. H. W. Gall \\ Pembroke College, Cambridge
}

(Text-figs. I-I3)

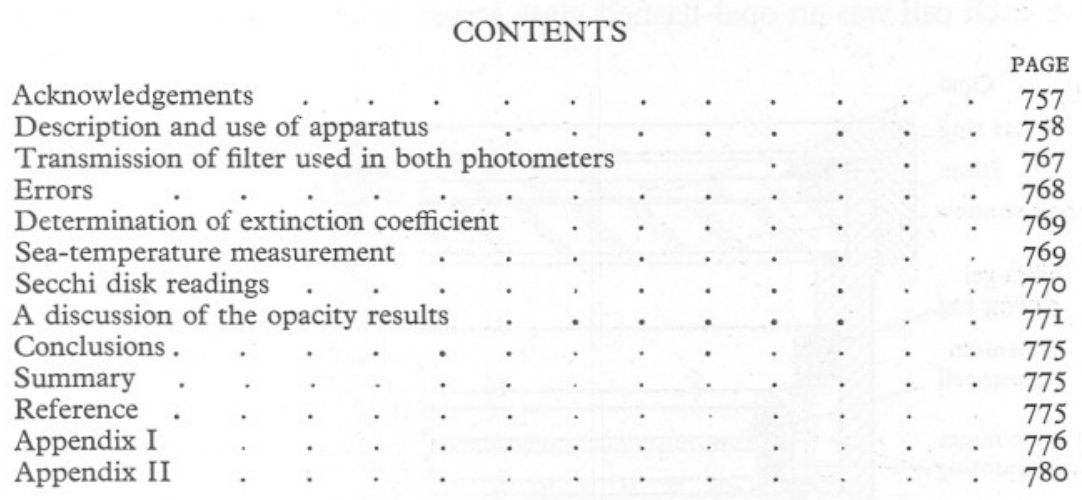

This is an account of work undertaken in the yacht Colleen during July-September I948, to measure extinction coefficients of the sea and to collect plankton and sea-water samples in the southern part of the North Sea and English Channel.

The results of observations at twenty-five stations in the North Sea and English Channel are recorded, with descriptions of the apparatus used. Some laboratory experiments with the apparatus are described, and some of the difficulties encountered are discussed.

\section{ACKNOWLEDGEMENTS}

The encouragement I received from the Director of the Marine Biological Association really accounted for the expedition yielding these results.

I am deeply indebted to Dr W. R. G. Atkins, F.R.S. and to Dr H. H. Poole for their help in the writing of the paper, and for many suggestions concerning the interpretation of the results.

I am also grateful to many of the staff of the Marine Biological Association for their help and interest before and after the expedition took place.

I would like to express sincere thanks to the fifteen yachtsmen from Cambridge, Oxford and London who came to sea with me at various times 
throughout the summer of 1948 , and whose seamanship and patience, often under distressing conditions in spite of regular doses of Hyoscine, made the measurements possible.

All the apparatus was made by Messrs H. Tinsley \& Co. Ltd. and I am grateful for their co-operation in all my requests.

\section{Description and Use of Apparatus}

The apparatus for measuring opacity consisted of two matched selenium photocells of the barrier layer type, each in a sealed box with a perspex aperture (Fig. I). Each aperture was covered with a cellulose nitrate blue-green filter, the transmission curve of which is given in Fig. II, p. 768. Immediately above each cell was an opal-flashed glass screen to diffuse the light. Bi-cored

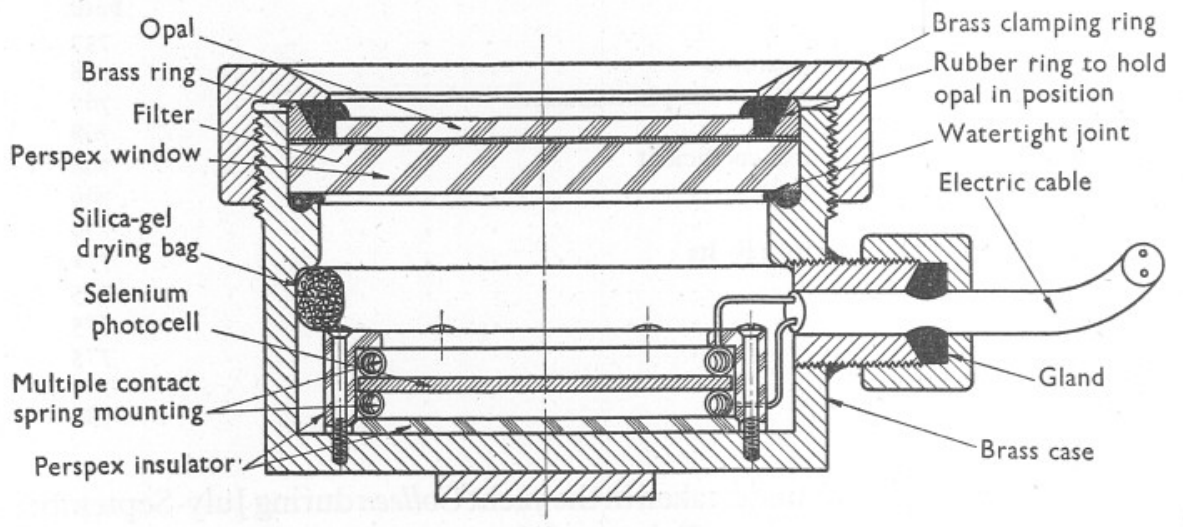

Fig. I. Submarine photometer, in section.

rubber-covered electric cable was sealed into each box. The sea cell was suspended in a cradle (Fig. 2) to which the cable was suitably fastened for lowering. The deck cell was fixed to a wooden wedge (Fig. 2), which brought the surface of the cell horizontal when placed on the deck-house roof. The sea cell had about $30 \mathrm{~m}$. of marked electric cable attached to it, and could be lowered into the sea over a pulley at the end of a I4 ft. spar which kept it clear of shadows round the ship (Fig. 2 shows a model set up).

The inboard ends of the cables from both photocells were connected to a ratiometer (Figs. 3 and 4) consisting of a $200 \Omega$ resistance across each cell, the positive sides of each resistance were made common and a null point was found between the negative side of the sea-cell resistance and a point along the deck-cell resistance by means of a specially constructed galvanometer. ${ }^{1}$ This null point determined the ratio of the cell currents, and hence the ratio of the cell illuminations, provided the cells had linear response curves.

1 Full details will be published elsewhere. 


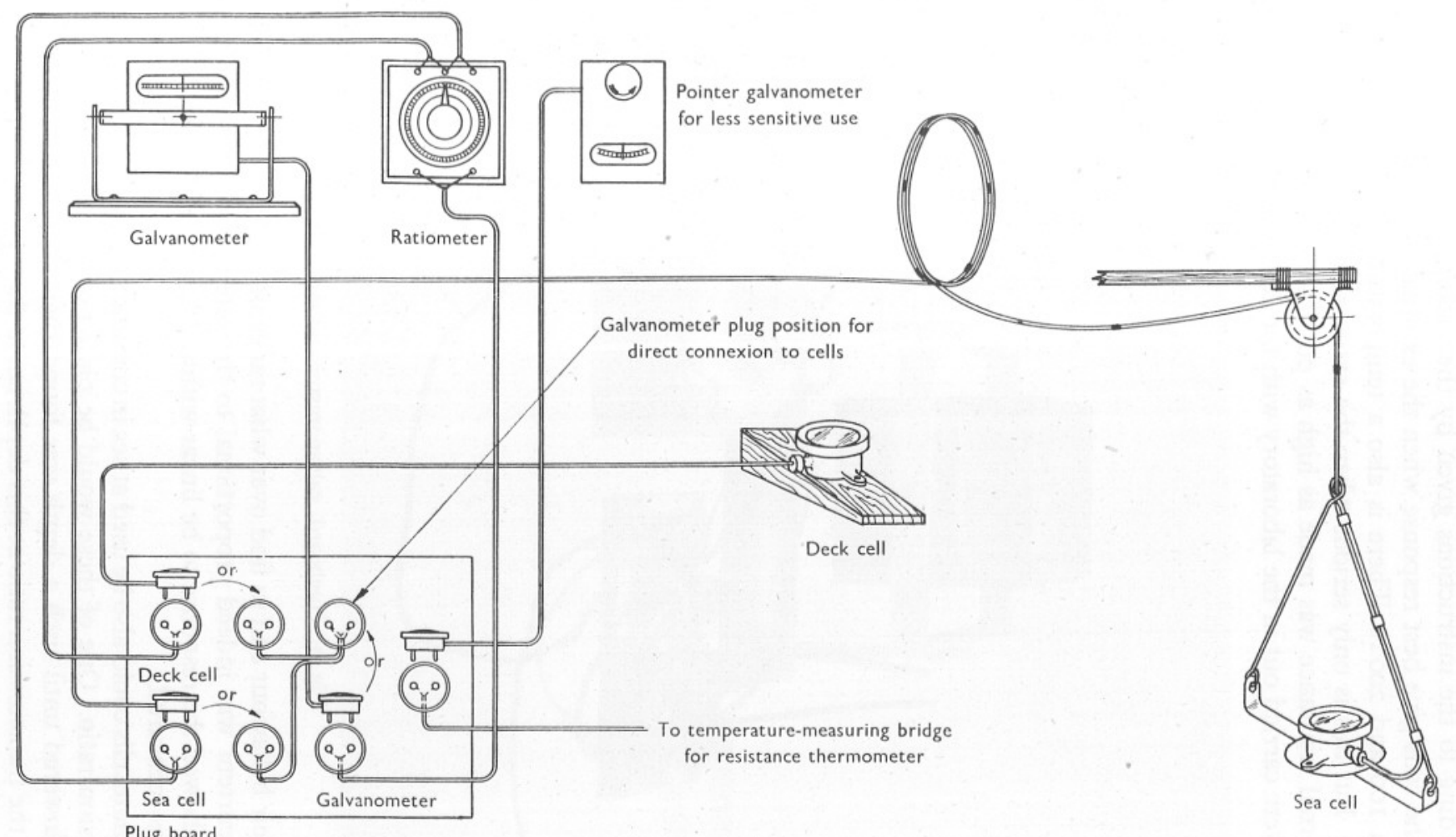

3

Fig. 2. Diagram of the photoelectric opacity apparatus. 
According to the instructions given by the makers (the Magnetron Company), the cells give best response when the external resistance across each is between 100 and $200 \Omega$. There is also a temperature coefficient to be considered. But this is only serious when the external resistance is very low, so the external resistance was made as high as possible, namely $200 \Omega$. Experiments were carried out in the laboratory with the cells actually used at sea, to

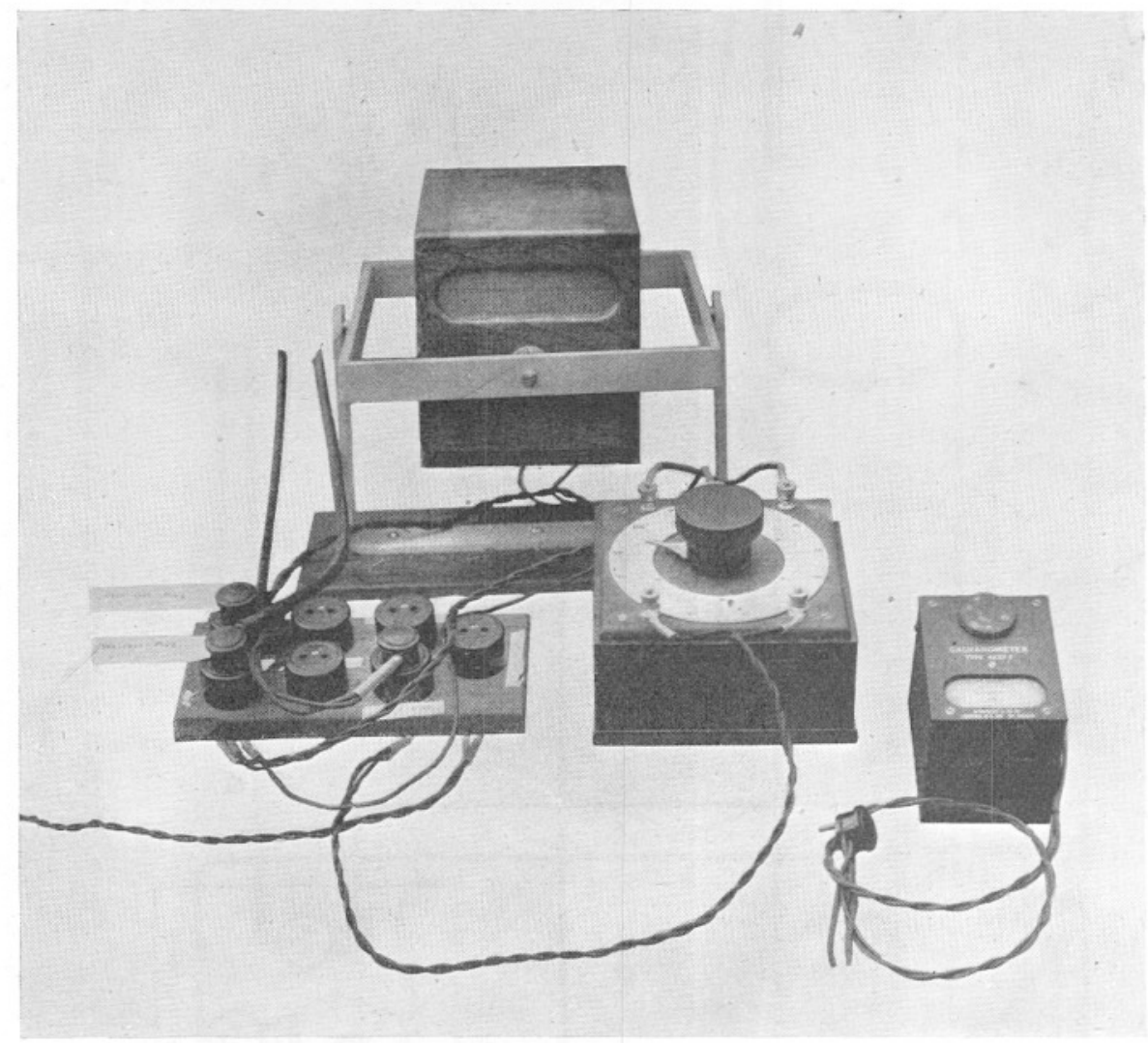

Fig. 3. Plugboard, galvanometer and radiometer.

study their behaviour and to find over what range of light intensity the photoelectric current was indeed proportional to the intensity of the illumination. Results showed the response to be linear within I \% , from Ioo to $5 \%$ of light intensities measured.

The photocells could also be used at sea in conjunction with filters of a known transmission ratio. One of these would be placed over the deck cell, and the sea cell lowered until such a depth was found that both cells gave the same current, the transmission ratio at this depth could then be considered the same as that of the filter placed over the deck cell. This method was used only as 
a check on the ratiometer method. The apparatus consisted simply of a galvanometer placed across the cells connected in parallel. The galvanometer in this case offers the same external resistance to each cell and was $200 \Omega$. Fig. 5 shows a circuit diagram.

The method of using the photoelectric apparatus was first to set up both the deck cell and sea cell side by side on deck in such a position that they were both free from shadows and received light from all directions. An initial reading made in this way always showed the sea cell to be slightly more sensitive than the deck cell. The sea cell was next rigged over a large pulley at

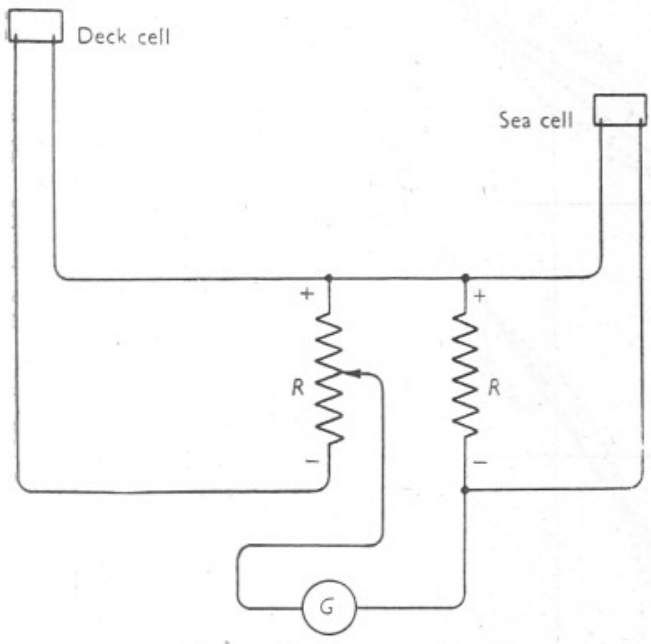

Fig. 4. Ratiometer circuit.

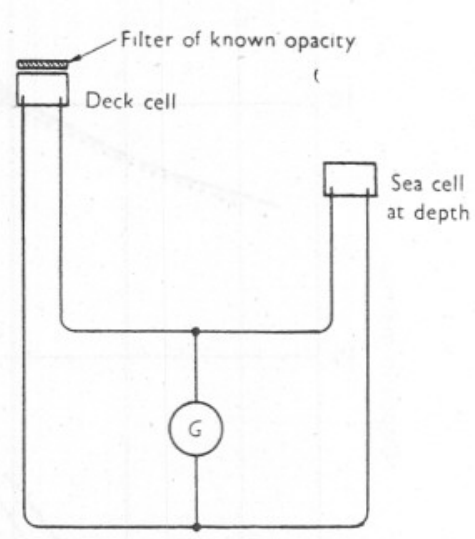

Fig. 5. Comparator circuit.

the outboard end of a I4 ft. spar placed over the ship's side in the manner shown in Fig. 2. This was always put out in a direction towards the sun, so that it was clear of any shadows under the ship.

The ratio of sea-cell current to deck-cell current was then measured, with the sea cell hanging clear of the surface and was always less than the 'on deck' ratio due to the lowering cradle being above the sea cell, thereby shielding some light off it. Finally the sea-cell was submerged to suitable depths and a series of ratiometer readings made.

The deck cell was not built on gimbals, but swung with the ship. As long as the sun was not shining, or was high enough not to cast a serious shadow from the rim of the cell across the deck cell, readings were fairly easy to make. Even when the ship was rolling considerably, the setting of the ratiometer which made the galvanometer deflexion zero could be satisfactorily determined. Violent jumping of the galvanometer spot at once told the observer down below that something was wrong with the deck cell, and that either the helmsman had let the ship's head full off so that the sun was causing shadows 
762

M. H. W. GALL

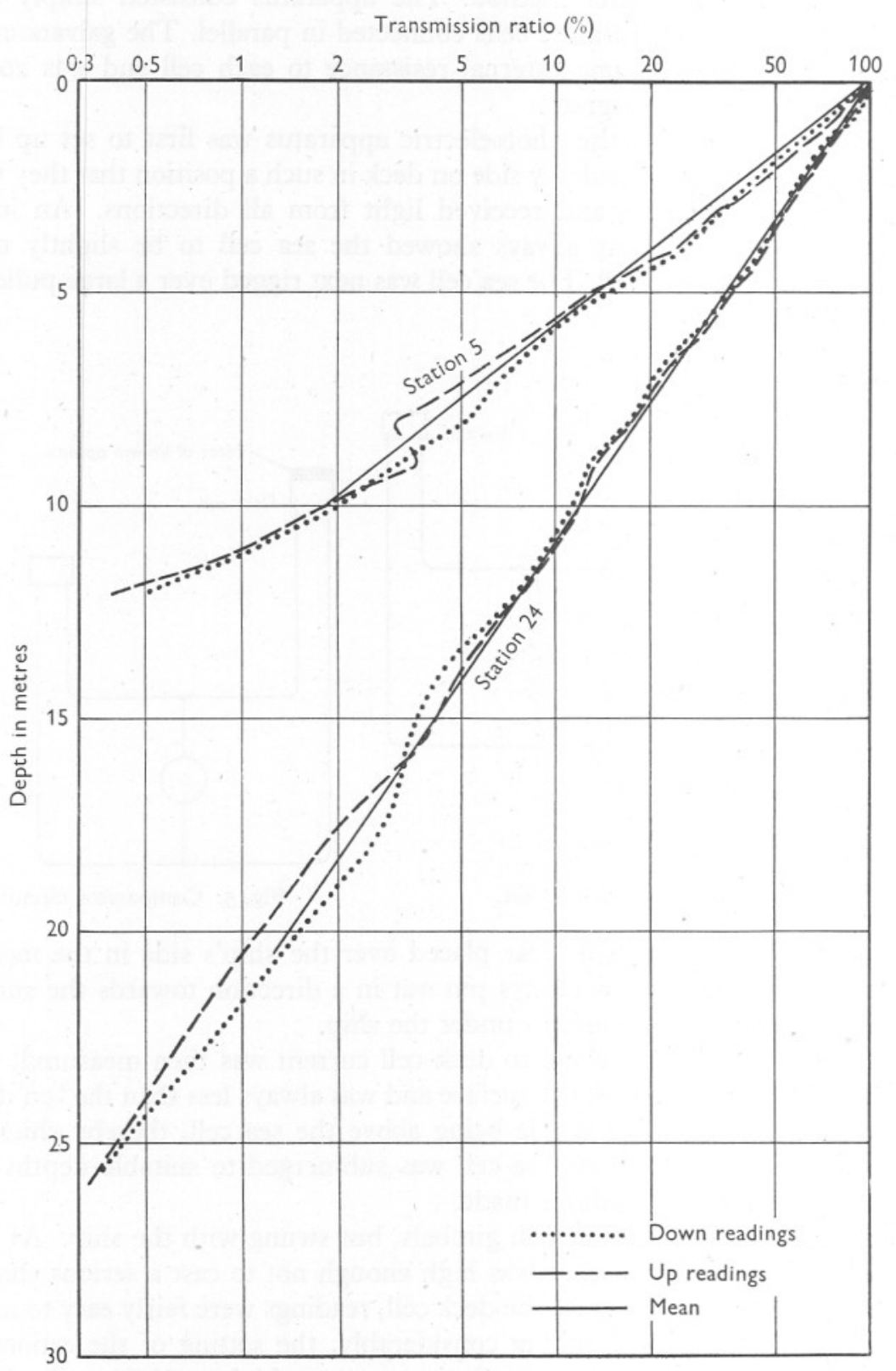

Fig. 6. Transmission ratio curves for stations 5 and 24 . 
from the rigging to dart across the deck cell, or that someone had carelessly walked too near the deck cell.

Even under unfavourable conditions, namely low sun and much rolling, once the sea cell was below about $10 \mathrm{~m}$., the measurements became fairly easy.

In each reading the ratiometer was adjusted to make the mean deflexion of the galvanometer zero. It can be argued that more accurate results would

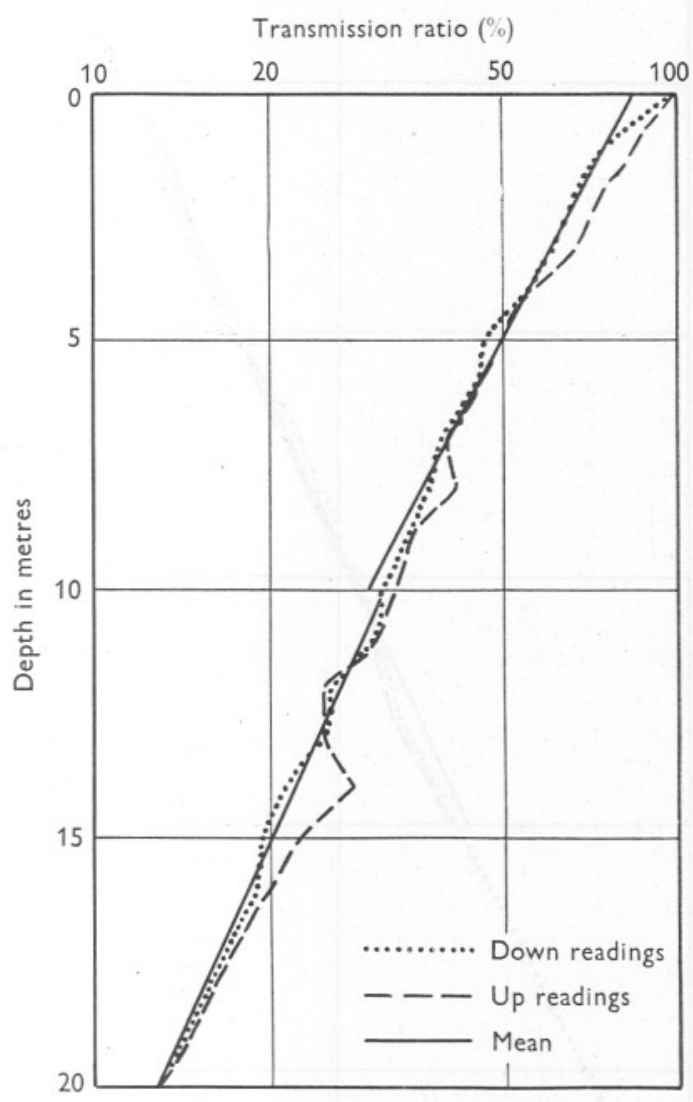

Fig. 7. Transmission ratio curve for station 7 .

have been obtained if the adjustment had been made so that the maximum deflexion of the galvanometer had been made zero, corresponding to the maximum illumination of the deck cell as the ship rolled. The very special nature of the galvanometer used for these measurements, which had a sensitivity of $6 \mathrm{~mm}$. per microampere and a periodic time of about $\frac{1}{20} \mathrm{sec}$., and suspended so as to operate independently of its orientation, caused it to follow these variations like an oscillograph. In practice, the results were more consistent by taking the mean position. 


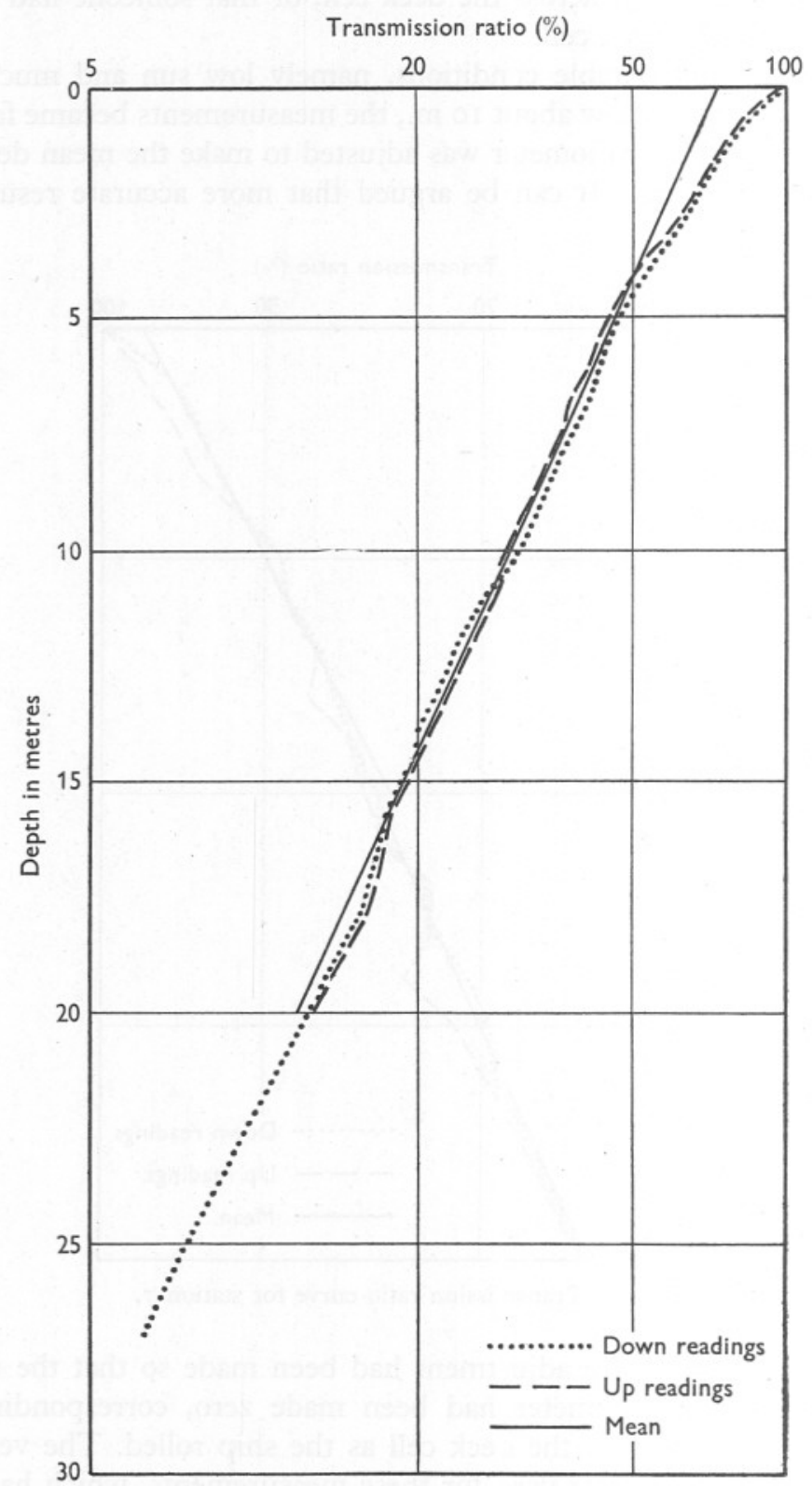

Fig. 8. Transmission ratio curve for station 8 . 


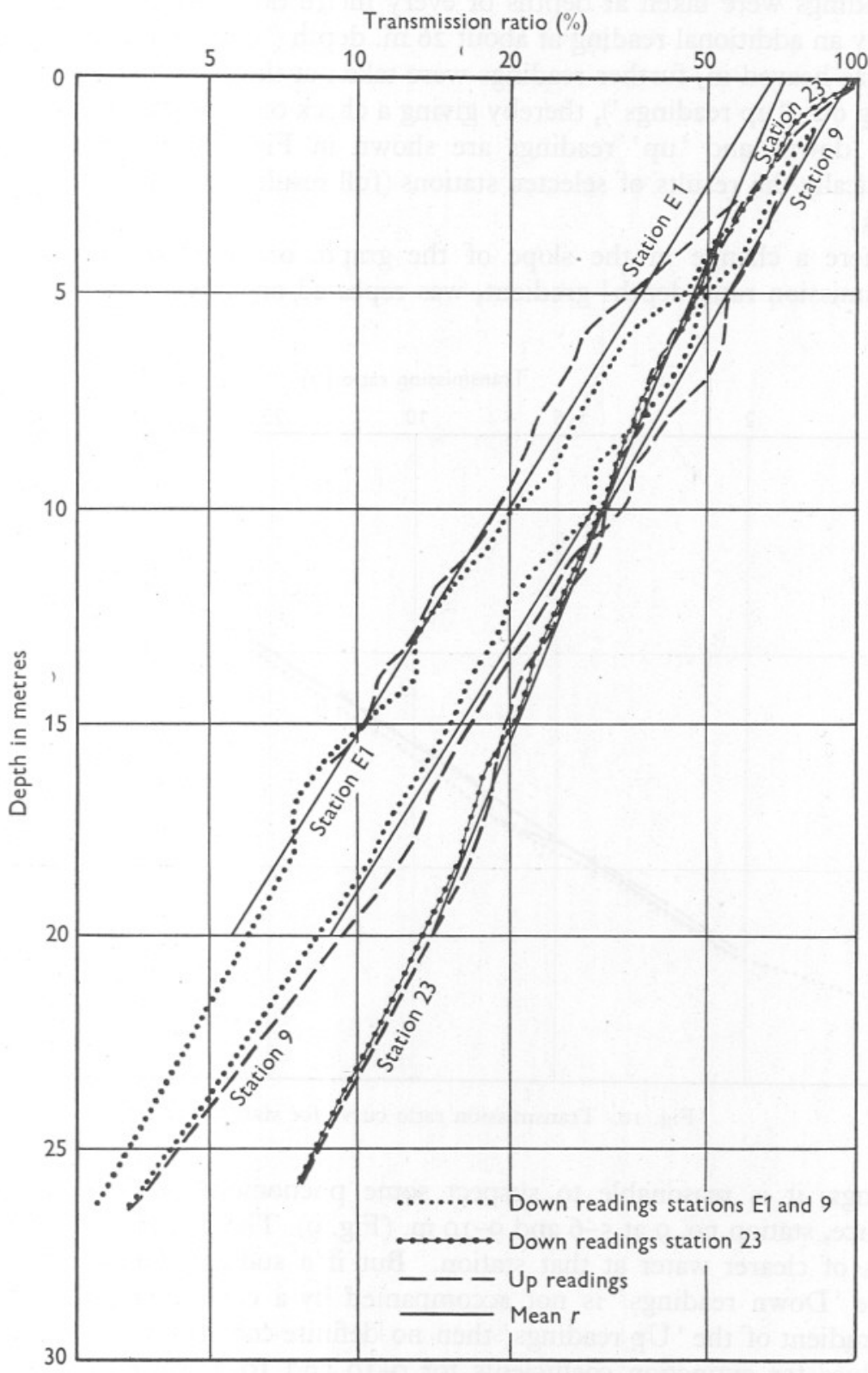

Fig. 9. Transmission ratio curves at stations $\mathrm{Er}, 9$, and 23. 
Readings were taken at depths of every metre down to about I8 m., and usually an additional reading at about $26 \mathrm{~m}$. depth ('down readings'). As the cell was heaved in, further readings were taken at the same depths as during paying out ('up readings'), thereby giving a check on the value at each depth. Both 'down' and 'up' readings are shown in Figs. 6-ro, which express graphically the results of selected stations (full results are given in Table II, p. 773).

Where a change in the -slope of the graph, or, more explicitly, of the 'transmission ratio/depth' gradient, was repeated on upward and downward

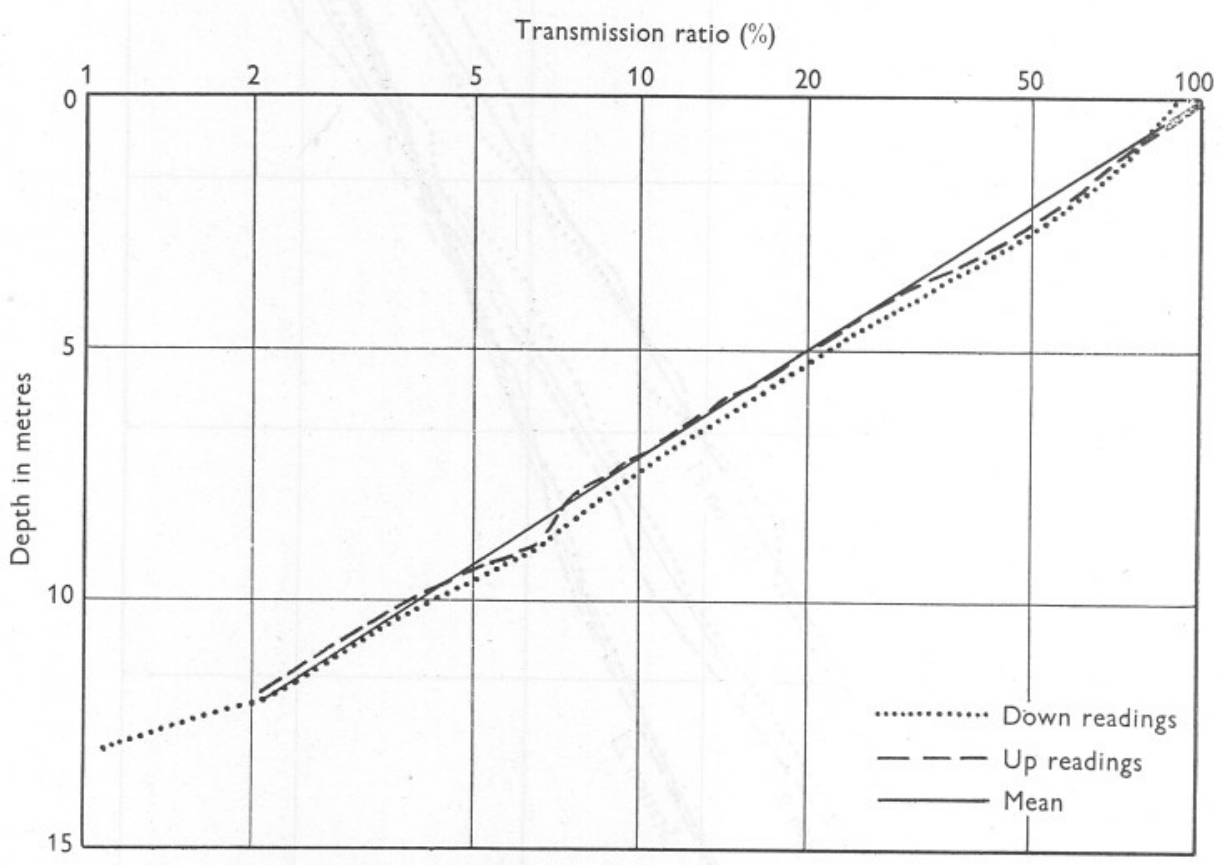

Fig. Io, Transmission ratio curve for station I2.

readings, it is reasonable to suspect some phenomena at that depth; for instance, station no. 9 at 5-6 and 9-10 m. (Fig. 9). There appear to have been layers of clearer water at that station. But if a sudden change in gradient in the 'Down readings' is not accompanied by a corresponding change in the gradient of the 'Up readings' then no definite conclusions can be drawn.

Values for extinction coefficients for 0-10 and $10-20 \mathrm{~m}$. depth, given in Table II on p. 773, were derived from the mean slope of the 'up' and 'down' readings for those ranges of depth-plotted as straight lines in Figs. 6-10, in addition to the curves for the 'down' and 'up' readings. The formula used for deriving the extinction coefficient is given on p. 769 . 
Inconsistencies in the graphs are believed to be caused either by bad weather, when the depth of the sea cell was not always very certain, or by turbulent layers of subsurface currents which made the sea cell ride up so that its real depth was considerably less than the amount of cable paid out. The curve for station no. 7 (Fig. 7) is an example of this, particularly at 8 and I4 m. depth.

At station no. 5 (Fig. 6) there were patches of visibly opaque water drifting about, and these caused big changes in both Secchi disk readings and transmission ratio when the ship passed through one. The graph is made up of results obtained in clear patches.

Station no. E I (Fig. 9) is an example of bad weather results. Station no. I2 (Fig. Io) is a straightforward example of rather high opacity. Station no. 8 (Fig. 8) is an example showing possible underwater currents at 7 and $14 \mathrm{~m}$. and apparently a layer of rather opaque water at the surface down to $4 \mathrm{~m}$., but this may be due to the shading of the ship giving false readings near the surface. Station no. 23 (Fig. 9) is a straightforward example of low opacity but apparently showing a surface layer of high opacity, this may be due to the shading of the ship. Station no. 24 (Fig. 6) shows a good agreement between readings taken when lowering and when raising the sea cell, in spite of the water being very turbulent.

The details of other stations are left out of the text, but all the results are brought together in Table II (p. 773).

\section{Transmission of Filter Used in both Photometers}

An experiment was carried out to determine the wave-length transmission curve of the filters used in the photometers. The apparatus used consisted of a spectrometer in which the field was split in two. In one half the light passed through the filter, in the other half through a sheet of polaroid. Light reached the spectrometer from a 'Pointolite' source through a collimator and a mounted Nicol's prism.

A spectrum was produced in the eyepiece by means of a diffraction grating. The intensity of the part of the field that passed through the polaroid could be controlled by the orientation of the Nicol, the intensity obeying a sine-squared law, the total extinction position being taken as zero angle.

The image seen in the eyepiece consisted of two spectra, one above the other. The bottom one being the light transmitted by the filter, the top one light transmitted by the polaroid. Having determined the extinction position of the Nicol, the cross-wires were set to different parts of the spectrum, the angle of deviation being read and the Nicol adjusted so that at the vertical cross-wire both halves of the field matched in intensity. If $\theta$ is the angle of deviation of light through the grating, then

$$
\lambda=d \sin \theta
$$

where $d$ is the line spacing of the grating and $\lambda$ is the wave-length, and plotting 
$d \sin \theta$ against $\sin ^{2} \phi$ (where $\phi$ is the angle of orientation of the Nicol) gives a transmission/wave-length graph.

Experimental values are given in Table I, and a smoothed curve plotted from them in Fig. II. The position of the first sodium line was also determined, giving a check on the wave-length values.

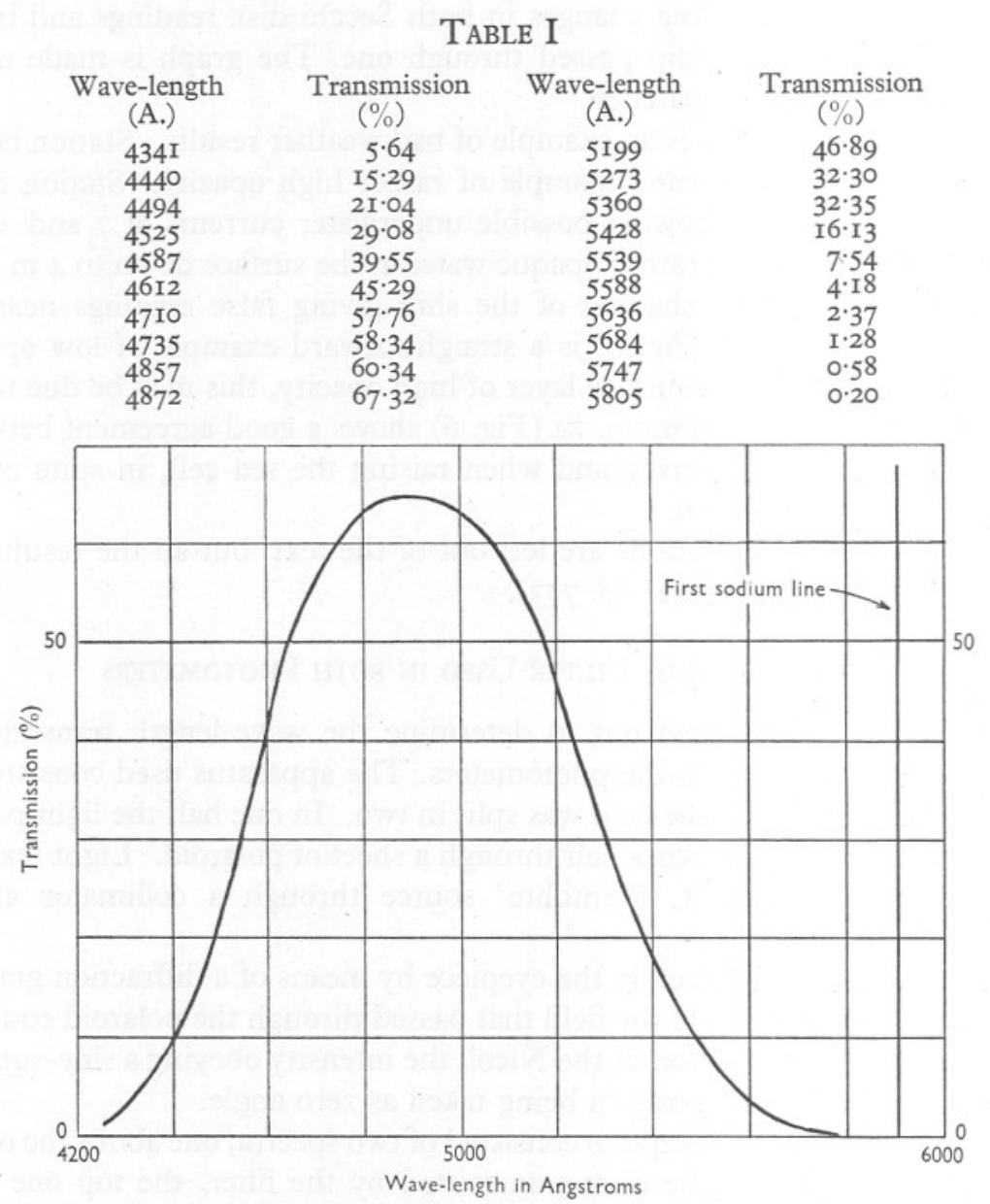

Fig. II. Transmission ratio curve for the photometer filters.

\section{ERRORS}

The quantity measured by the ratiometer has been called 'transmission ratio'. The ratiometer does not measure a true ratio of light-at-depth to light-at-surface, owing to three types of error: (i) the internal and external reflexion factor (see Atkins \& Poole, 1933), (ii) errors due to difference in 
sensitivity of the two cells, and (iii) error due to shading of low-angle sky by the rim of the photometer. These errors are consistent, and after suitable calibration a measurement of a real ratio could be made. There are, however, two random errors for which corrections cannot easily be made: they are (i) error in estimating the depth of the sea cell, and (ii) error due to surface reflexion at the sea surface. The first of these random errors lay in not knowing the exact depth of the instrument, due to drag on its supporting cable, caused by the ship making leeway. This was only serious where the wind was force 3 or more. An efficient depth-recording instrument fitted to the submarine instrument would permit measurements to be made in winds up to force 5 . The second correction is a matter of experience. The photoelectric current ratios for Secchi disk readings shown in Table III are subject to the same errors.

\section{Determination of Extinction CoefFicient}

Since no absolute measurements of light were made but only light ratios ascertained, there is no point in determining more than the extinction coefficient at each station, and this has been done by taking the mean gradient between O-IO and IO-20 m. depth of the ' $\log$ transmission ratio/depth' curves for each station and using the following formula:

$$
P_{5}=\frac{2 \cdot 3\left(\log r_{0}-\log r_{10}\right)}{\text { IO }}, \quad P_{15}=\frac{2 \cdot 3\left(\log r_{10}-\log r_{20}\right)}{\text { IO }},
$$

where $P_{5}=$ extinction coefficient at $5 \mathrm{~m}$. depth, $P_{15}=$ that at $15 \mathrm{~m}$. depth, $r_{0}=$ transmission ratio at surface, $r_{10}=$ that at $\mathrm{IO} \mathrm{m}$. and $r_{20}=$ that at $20 \mathrm{~m}$. depth.

\section{Sea-Temperature MEASUREMENT}

A resistance thermometer was used to measure the temperature of the sea at different depths. It consisted of fine platinum wire on a threaded former about $\mathrm{I}$ in. long; $\frac{1}{4}$ in. diameter enclosed in a tube. The resistance was about IOO $\Omega$ at $0^{\circ} \mathrm{C}$. The tube was fixed to the end of 3 -cored rubber-covered copper cable.

Compensation for the resistance of the copper cable is effected by using the 3 -cored cable, and thus having an equal amount of copper resistance in opposite arms of the bridge. The third core of the cable is connected to the end of the platinum thermometer and goes to the galvanometer. By this arrangement, the copper cable is equally divided between the two arms of the bridge so that variations in its resistance with temperature are compensated. The two cores of the cable having the most equal resistance are chosen for this purpose.

The thermometer has been calibrated directly experimentally, and a table drawn up for interpolating measurements made at sea. Fig. I2 shows a 
diagram of the thermometer bridge. At sea the calibration was checked at each set of readings by making a temperature measurement at the surface with a mercury thermometer.

Temperature measurements were usually made at the same time as the opacity measurements, and the nature of the temperature gradient determined down to $20 \mathrm{~m}$. depth. These results are tabulated, together with the extinction coefficients. The temperature gradients were in no cases large (usually of the order of 0.02 degrees per metre) they are indicated in the last column of

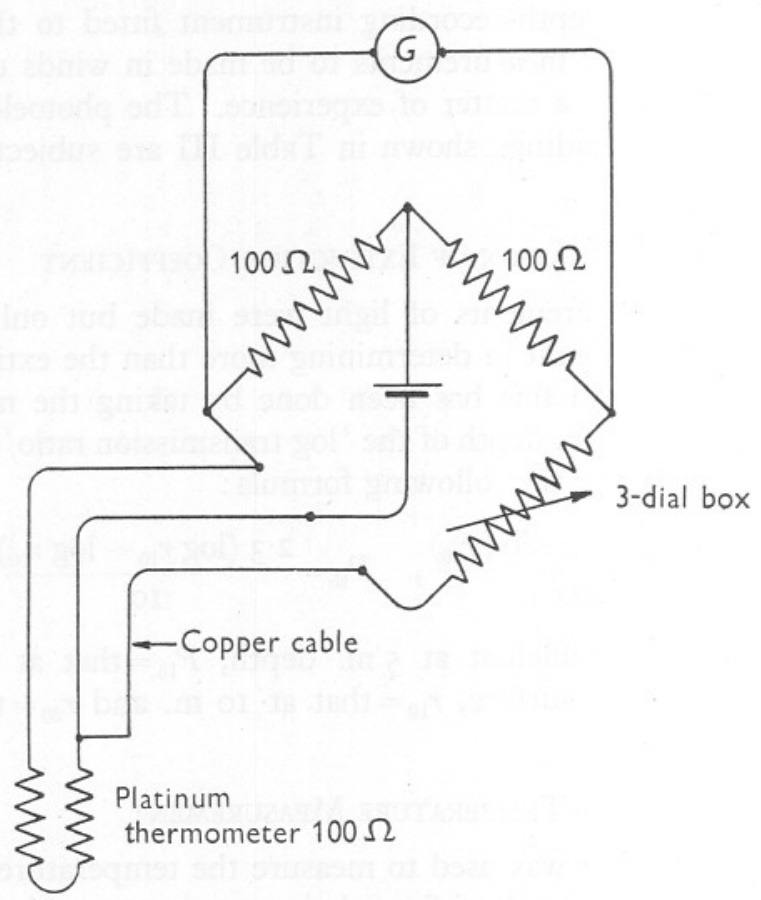

Fig. I2. Circuit of thermometer bridge.

Table II (p. 773), a plus sign means the temperature falls with depth, a negative sign means it increases with depth and a zero sign means no appreciable change.

\section{SeCCHI Disk REAdings}

Readings were taken with a I2 in. Secchi disk at each station, even when weather conditions were too bad for photoelectric measurements to be made, and there are a sufficient number of contemporary Secchi disk and photoelectric readings to interpret any Secchi disk reading taken when no photoelectric reading was taken as an extinction coefficient to within certain limits of accuracy (see Table III, p. 774). 
It is interesting to notice the relationship between Secchi disk readings and the transmission ratio at the depth at which the Secchi disk disappeared as measured photoelectrically.

Very roughly, the Secchi disk disappears from view at a depth where transmission ratio is approximately $20 \%$, but from the data available (see Table III) it varies from I6.I to $25.0 \%$. The mean of all the values is $20 \cdot 7$ with a standard deviation of 3.0 . By placing the readings in columns, for conditions of bright sun, no sun, rough sea and calm sea, etc., we should expect to get a smaller error for each set of conditions. Unfortunately there are not enough readings available to draw satisfactory conclusions (see Appendix II, p. 780), but the indications are as follows:

(i) In a rough sea, whether there is no sun or intermittent sun, the transmission ratio at which the Secchi disk fades out is of the order of $24 . \mathrm{I} \%$. (There are insufficient readings to show whether sun or no sun really makes a difference, still less to show the degree of error.)

(ii) In a calm sea, the transmission ratio at which the Secchi disk fades out is about $19.5 \%$, possibly a little higher in bright sun than when overcast $(20.4$ and $18.6 \%$ are values for bright sun and no sun, but the difference is scarcely significant). The lower value for a calm sea as opposed to a rough sea is suggestive.

(iii) The standard deviation $(\sigma)$ for all 'calm sea' readings is estimated as $2 \cdot 7$. For calm sea 'with bright sun' (seven readings) it is $2 \cdot 8$, and for calm sea 'with no sun' (five readings) it is $\mathrm{I} \cdot 9$. The latter conditions would be expected to be ideal, and do in fact produce more consistent readings than those in bright sun (as far as significance can be attached to the relatively low value of $\sigma=\mathrm{I} \cdot 9$ ). But the increase in consistency cannot be called very great.

\section{A Discussion of Opacity Results}

The positions of the stations and the main results from them are given in Table II, and further details from some stations respecting Secchi disk measurements are given in Table III. The course taken by the yacht can be seen on the accompanying map (Fig. 13), on which are also marked station numbers and grades of opacity of the water.

The particulars in Table II include extinction coefficients, which have been determined from measurements of the light transmission with depth and from Secchi disk readings, ${ }^{1}$ and temperature measurements at the middle of the two depth ranges for which extinction coefficients were calculated.

From Table II it will be noticed that in the southern North Sea extinction coefficients of between 0.40 and 0.092 were obtained (except for one station

\footnotetext{
${ }^{1}$ A sufficient number of contemporary Secchi disk readings and photoelectric readings were made for independent Secchi disk readings, to be interpreted as extinction coefficients within sufficient accuracy for many purposes. See also above, p. 770 .
} 


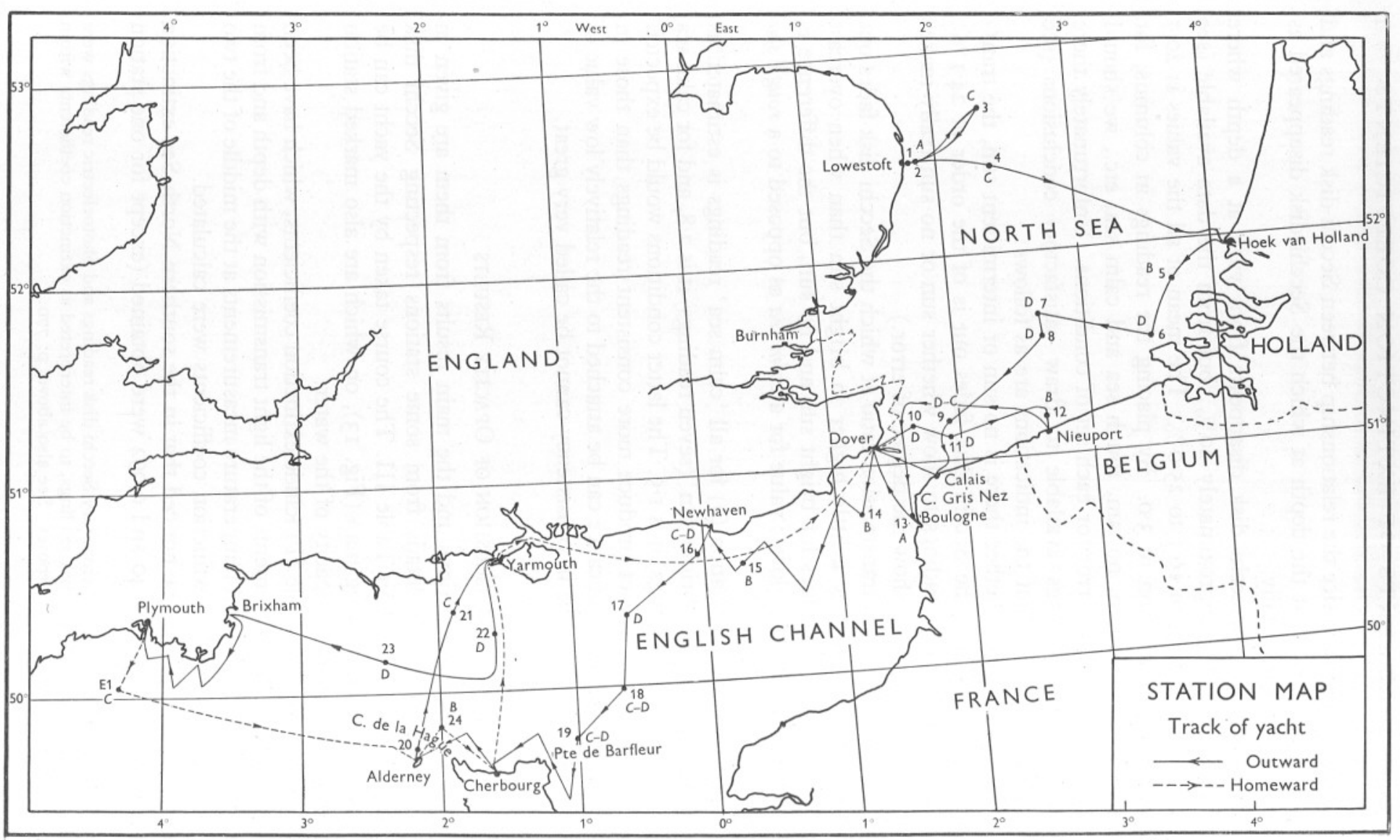

Fig. I3. Map showing the course of the yacht and the position of stations at which readings were taken. 
Table II. Positions of Stations Worked and Main Results of the Light and Temperature Measurements

\begin{tabular}{|c|c|c|c|c|c|c|c|c|c|c|}
\hline \multirow{2}{*}{$\begin{array}{c}\text { Station } \\
\text { no. }\end{array}$} & \multirow[b]{2}{*}{ Position } & \multirow[b]{2}{*}{ Date } & \multicolumn{2}{|c|}{$\begin{array}{l}\text { Extinction } \\
\text { coefficient }\end{array}$} & \multirow{2}{*}{$\begin{array}{l}\text { Secchi } \\
\text { disk } \\
(\mathrm{m} .)\end{array}$} & \multirow{2}{*}{ Opacity } & \multirow{2}{*}{$\begin{array}{c}\text { Salinity } \\
(\% / \infty)\end{array}$} & \multicolumn{3}{|c|}{ Temperature ( ${ }^{\circ} \mathrm{C}$.) } \\
\hline & & & o-Io m. & $10-20 \mathrm{~m}$. & & & & $5 \mathrm{~m}$. & I5 m. & Gradient \\
\hline I & $52^{\circ} 28 \cdot 8^{\prime}$ N., or $^{\circ} 47 \cdot 5^{\prime} \mathrm{E}$. & I5. vii. 48 & $I \cdot 24$ & - & $I_{4}^{1}$ & A & $33.8 \mathrm{I}$ & $14 \cdot I$ & - & - \\
\hline 2 & $52^{\circ} 29^{\circ} 4^{\prime} \mathrm{N} .$, OI I $^{\circ} 52^{\circ} 0^{\prime} \mathrm{E}$. & I5. vii. 48 & - & - & 3 & $A$ & 300 & 13.0 & $12 \cdot 9$ & + \\
\hline 3 & $52^{\circ} 43^{\prime} 8^{\prime}$ N., $02^{\circ}$ I $8 \cdot 2^{\prime}$ E. & I6. vii. 48 & $0 \cdot 143$ & 0.139 & $12 \frac{1}{4}$ & $C$ & $34 \cdot 31$ & I3. I & $13 \cdot \mathrm{I}$ & 0 \\
\hline 4 & $52^{\circ} 26 \cdot 8^{\prime}$ N., $02^{\circ} 24 \cdot 5^{\prime}$ E. & I9. vii. 48 & - & - & II & C & 345 & 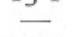 & 20 & - \\
\hline 5 & $5 \mathrm{I}^{\circ} 5 \mathrm{I} \cdot 0^{\prime} \mathrm{N} ., \mathrm{O}^{\circ} 38 \cdot 0^{\prime} \mathrm{E}$. & 23. vii. 48 & 0.396 & - & IO $\frac{1}{2}, 3 \frac{1}{4}$ & $B, A$ & $32 \cdot 73$ & 13.5 & $13 \cdot 3$ & + \\
\hline 6 & $5 \mathrm{I}^{\circ} 35^{\circ} 0^{\prime} \mathrm{N} ., \mathrm{O}^{\circ} 29^{\circ} 0^{\prime} \mathrm{E}$. & 23. vii. 48 & - & - & I $5 \frac{1}{4}-16 \frac{3}{4}$ & $D$ & 35.07 & 15.0 & I5.0 & 0 \\
\hline 7 & $5 \mathrm{I}^{\circ} 48.5^{\prime}$ N., $\mathrm{O}^{\circ} 38.5^{\prime} \mathrm{E}$. & 24. vii. 48 & $0 \cdot 104$ & 0.092 & I3 & $D$ & $35 \cdot 25$ & 14.5 & $14 \cdot 6$ & - \\
\hline 8 & $5 \mathrm{I}^{\circ} 36 \cdot \mathrm{I}^{\prime} \mathrm{N} ., \mathrm{O}^{\circ} 4 \mathrm{I} \cdot 2^{\prime} \mathrm{E}$. & 24. vii. 48 & 0.088 & 0.092 & $13 \frac{1}{2}$ & $D$ & - & 15.4 & $15 \cdot 3$ & + \\
\hline 9 & $5 \mathrm{I}^{\circ} \mathrm{I} 2.0^{\prime} \mathrm{N}, \mathrm{OI}^{\circ} 54^{\circ} 0^{\prime} \mathrm{E}$. & 25. vii. 48 & 0.101 & 0.124 & II $\frac{1}{2}$ & $D-C$ & 一 & $16 \cdot I^{4}$ & $16 \cdot 1$ & 0 \\
\hline IO & $5 \mathrm{I}^{\circ}$ II $\cdot 8^{\prime} \mathrm{N} .$, or $^{\circ} 39^{\circ} 0^{\prime} \mathrm{E}$. & 29. vii. 48 & 0.097 & 0.097 & $14 \frac{1}{2}$ & $D$ & $35 \cdot 23$ & $15 \cdot 4$ & $15 \cdot I$ & + \\
\hline II & $5 \mathrm{I}^{\circ} 08 \cdot 0^{\prime} \mathrm{N} ., \mathrm{or}^{\circ} 57^{\circ} \mathrm{O}^{\prime} \mathrm{E}$. & 29. vii. 48 & O.III & 0.109 & 15 & $D$ & - & 15.9 & $15 \cdot 7$ & + \\
\hline 12 & $5 \mathrm{I}^{\circ}$ II $\cdot 5^{\prime}$ N., $02^{\circ} 4 \mathrm{I} \cdot 5^{\prime} \mathrm{E}$. & 3o. vii. 48 & $0.32 \mathrm{I}$ & - & $5 \frac{1}{2}$ & $B$ & 一 & 18.0 & 17.9 & + \\
\hline 13 & $50^{\circ} 46 \cdot 2^{\prime}$ N., OI $^{\circ} 34^{\circ} 0^{\prime} \mathrm{E}$. & 5. viii. 48 & - & - & 3 & $A$ & - & $18 \cdot 2$ & I8.0 & + \\
\hline 14 & $50^{\circ} 47 \cdot 0^{\prime} \mathrm{N}, \mathrm{OI}^{\circ} \mathrm{I} 2 \cdot 0^{\prime} \mathrm{E}$ & I0. viii. 48 & 0.247 & - & $6 \frac{3}{4}$ & $B$ & $35 \cdot 40$ & 14.6 & 14.7 & 0 \\
\hline 15 & Beachy Head 7 miles $332^{\circ}$ true & II. viii. 48 & - & - & 7 & $B$ & $35 \cdot 18$ & 14.9 & $14 \cdot 7$ & + \\
\hline 16 & $50^{\circ} 36 \cdot 0^{\prime} \mathrm{N} ., 0^{\circ} 03 \cdot 2^{\prime} \mathrm{W}$. & I4. viii. 48 & 0.123 & 0.110 & - & $C-D$ & 3. & I6.0 & I5. 5 & + \\
\hline 17 & $50^{\circ} 2 \mathrm{I} \cdot 0^{\prime} \mathrm{N}, 0^{\circ} 340^{\prime} \mathrm{W}$ & I5. viii. 48 & - & - & 12 & $D$ & 一 & - & 135 & - \\
\hline 18 & $50^{\circ} 0.0^{\prime}$ N., $0^{\circ} 380^{\prime} \mathrm{W}$ & I6. viii. 48 & 0.136 & 0.097 & IO & $C-D$ & $35 \cdot 30$ & $15 \cdot 2$ & $15 \cdot 2$ & 0 \\
\hline 19 & $49^{\circ} 45^{\circ} \mathrm{O}^{\prime} \mathrm{N} ., \mathrm{or}^{\circ} \mathrm{O} \mathrm{O}^{\prime} \mathrm{W}$ & I6. viii. 48 & 0.128 & 0.082 & I0 & $C-D$ & - & $16 \cdot 0$ & 15.9 & + \\
\hline 20 & 2 miles due North Alderney lighthouse & 20. viii. 48 & - & - & II $\frac{1}{2}$ & $C$ & - & I 4.7 & 14.5 & + \\
\hline $2 I$ & $50^{\circ} 23^{\prime}$ N., OI $^{\circ} 5 I^{\prime} \mathrm{W}$. & 2I. viii. 48 & 0.136 & $0 \cdot 137$ & 10 & C & - & 15.0 & 14.9 & + \\
\hline 22 & $50^{\circ} 16.5^{\prime}$ N., or $^{\circ} 33^{\prime} \mathrm{W}$. & 24. viii. 48 & 0.108 & 0.098 & $13 \frac{1}{2}$ & $D$ & - & $15 \cdot 2$ & $15 \cdot 2$ & 0 \\
\hline 23 & $50^{\circ} 07 \cdot 5^{\prime}$ N., $02^{\circ} 2 \mathrm{I} \cdot 5^{\prime} \mathrm{W}$. & 24. viii. 48 & 0.084 & 0.079 & 13 & $D$ & 一 & $\mathrm{I} 5 \cdot \mathrm{I}$ & I5. I & 0 \\
\hline $\mathrm{E}_{\mathrm{I}}$ & $50^{\circ} 04^{\circ} 0^{\prime} \mathrm{N} ., 04^{\circ} 22 \cdot 0^{\prime} \mathrm{W}$. & 6. ix. 48 & 0.123 & 0.122 & 9 & C & $35 \cdot 33$ & - & - & - \\
\hline 24 & $49^{\circ} 47 \cdot 5^{\prime}$ N., $02^{\circ}$ or $\cdot 0^{\prime} \mathrm{W}$. & 9. ix. 48 & 0.215 & 0.208 & $7 \frac{1}{4}$ & $B$ & נדנה & - & - & - \\
\hline
\end{tabular}

Note. The opacity of the water (seventh column of Table) has been graded as follows: $A$, extinction coefficient $>0 \cdot 8$, Secchi disk $<4$ m.; $B$, extinction coefficient $0.2-0.8$, Secchi disk $5-8 \mathrm{~m}$; $C$, extinction coefficient $0.1 \mathrm{I}-0.2$, Secchi disk $9-\mathrm{I} 2 \mathrm{~m}$.; $D$, extinction coefficient $<0 . \mathrm{I}$, Secchi disk > $>2 \mathrm{~m}$. When the two depths fall into a different grade, both letters are given, that for $0-\mathrm{IO} \mathrm{m}$. being put first. At station No. 5 the Secchi disk reading $3 \frac{1}{4} \mathrm{~m}$. was taken in an opaque patch, other readings at this station were taken in clear water. 
close inshore off Lowestoft which gave a value of $\mathrm{I} \cdot 24$ ); while in the English Channel values ranged between 0.24 and 0.079 .

On the whole, the agreement between the $0-10$ and $0-20 \mathrm{~m}$. readings is close, though a difference of some $45 \%$ of the mean value was found at station no. I9. There the surface layer was the more opaque. An extreme instance of the same effect was visible at station no. 5, as mentioned already (p. 767).

On the other hand, at station no. 9 , in the vicinity of the Sandetti bank, the water became decidedly more opaque below Io $\mathrm{m}$. This was presumably due to suspended matter being taken off the top of the bank, but not mixing with the upper layers. Station no. 8, in the vicinity of the Hinder Sand, also shows an inversion of the extinction coefficient with depths, but to a smaller extent than at station no. 9 .

The extinction coefficients at station nos. 6-II are surprisingly low, as these stations are in shallow water, where there are currents of the order of $2 \frac{1}{2}$ knots, which would be expected to keep a great deal of matter in suspension.

\section{TABle III. Secchi Disk Data}

\begin{tabular}{|c|c|c|c|c|c|}
\hline $\begin{array}{l}\text { Station } \\
\text { no. }\end{array}$ & Date & $\begin{array}{l}\text { Secchi } \\
\text { disk } \\
\text { reading } \\
\text { (m.) }\end{array}$ & $\begin{array}{l}\text { Photoelectric } \\
\text { current } \\
\text { ratio }\end{array}$ & Sea conditions & Weather conditions \\
\hline $\mathrm{I}$ & I5. vii. 48 & $\mathrm{I}_{\frac{1}{4}}$ & $2 \mathrm{I} \cdot 5$ & Calm & Intermittent sun \\
\hline & 24. vii. 48 & I3 $\frac{1}{2}$ & & & No sun, hazy \\
\hline 9 & 25. vii. 48 & II $\frac{1}{2}$ & $24 \cdot 5$ & $\begin{array}{l}\text { Slight swell, ruffled } \\
\text { surface }\end{array}$ & Bright sun \\
\hline IO & 28. vii. 48 & $14 \frac{1}{2}$ & $23 \cdot 0$ & $\begin{array}{l}\text { Very slight swell and } \\
\text { sea calm }\end{array}$ & $\begin{array}{l}\text { Bright sun (I0.00 } \\
\text { G.M.T.) }\end{array}$ \\
\hline II & 29. vii. 48 & I5 & $16 \cdot I$ & $\begin{array}{l}\text { Slight swell and sea } \\
\text { calm }\end{array}$ & $\begin{array}{l}\text { Bright sun, haze } \\
\text { (I5.00 G.M.T.) }\end{array}$ \\
\hline I2 & 30. vii. 48 & $5 \frac{1}{2}$ & $18 \cdot 7$ & Very slight sea swell & $\begin{array}{l}\text { Bright sun (low), haze } \\
\text { (07.30 G.M.T.) }\end{array}$ \\
\hline I4 & Io. viii. 48 & $6 \frac{3}{4}$ & $17 \cdot 0$ & Slight sea and swell & No sun \\
\hline 18 & I6. viii. 48 & 14 & $17 \cdot 3$ & $\begin{array}{l}\text { Heavy swell, smooth } \\
\text { surface }\end{array}$ & No sun, grey sky \\
\hline I9 & I6. viii. 48 & IO & 25.0 & Sea rough, swell short & $\begin{array}{l}\text { Intermittent sun } 5 / \text { ro } \\
\text { cloud. Wind force } \\
3-4\end{array}$ \\
\hline $2 \mathrm{I}$ & 2I. viii. 48 & & $20 \cdot 0$ & Sea calm & Intermittent sun \\
\hline 22 & 24. vi & I3 $\frac{1}{2}$ & $18 \cdot 0$ & $\begin{array}{l}\text { Oily surface, moder- } \\
\text { ate swell }\end{array}$ & No sun, Io/ro cloud \\
\hline $\begin{array}{l}23 \\
24\end{array}$ & $\begin{array}{l}\text { 24. viii. } 48 \\
\text { 9. ix. } 48\end{array}$ & I3 & $\begin{array}{l}23.9 \\
19 \cdot 2\end{array}$ & $\begin{array}{l}\text { Small waves } \\
\text { Sea calm, turbulent }\end{array}$ & $\begin{array}{l}\text { Mist and drizzle } \\
\text { Bright sun }\end{array}$ \\
\hline E'I & 9. ix. 48 & $9-8 \frac{1}{2}$ & 23.5 & $\begin{array}{l}\text { Sea moderate, me- } \\
\text { dium swell }\end{array}$ & Intermittent sun \\
\hline
\end{tabular}

Note. When the sun is shining, its altitude and relative bearing would probably affect the Secchi disk reading, but it cannot be said with certainty whether more consistent results would have been obtained if these had also been considered. However, it is safe to say that in calm weather the Secchi disk depth is greatest when there is no sun and least when the sun is shining brightly, and in rough weather the Secchi disk depth is less than in calm weather. These observations are consistent with what might be concluded from considerations of surface reflexion under the respective weather conditions. 


\section{CONCLUSIONS}

The results show that it is possible to carry out opacity observations with an accuracy depending on the weather conditions. The table of Secchi disk results probably gives the best guide to the accuracy of the other opacity results. It is not possible to calculate the overall accuracy, as the random error of the depth of the instrument plays such an important part. The main feature of these results is that they show continuous sets of readings from which the extinction coefficient can be calculated, and changes in the transmission of light with depth observed down to $20 \mathrm{~m}$. The quantity that has been measured by the ratiometer is not an absolute measurement of the ratio of light at depth to light at surface but is a quantity proportional to this ratio and has been called transmission ratio. The results are probably of the order of $15 \%$ greater than the absolute ratio.

If an accurate depth-meter could be fitted to the submarine instruments, one of the largest sources of random error could be reduced and more satisfactory results obtained.

\section{SUMMARY}

During a cruise in the southern North Sea and English Channel in I948 a series of measurements on light penetration was secured.

The apparatus used has been described, and methods of handling it discussed. A description of the experiments for determining the transmission curve of the filters used in the photometers, has been included.

Of the systematic and random errors to which the photometer measurements were liable the most serious lay in not knowing the precise depth of the sea cell.

Extinction coefficients have been determined from the gradients of logarithmic transmission-ratio/depth graphs, and the results tabulated for each station.

Temperature gradients were never large, usually of the order of 0.02 degrees per metre, the temperature usually dropping with increased depth, frequently there was no gradient at all.

An attempt has been made to correlate Secchi disk readings with extinction coefficients, as far as the data permit.

Sea-water samples from ten stations show that generally the salinity is higher in areas of low opacity, the Beachy Head vicinity being the main exception to this.

The opacity results show clearer water than might be expected at certain stations (Nos. 6, 7, 8, IO and II) in the southern North Sea.

\section{REFERENCE}

Atkins, W. R. G. \& Poole, H. H., I933. The photo-electric measurement of the penetration of light of various wave-lengths into the sea and the physiological bearing of the results. Phil. Trans. Roy. Soc. B, Vol. ccxxir, pp. I29-64. 


\section{APPENDIX}

I

As specimens of the raw data, the particulars of six of the stations are given herewith:

Station No. 8

Time: I3.45 G.M.T. Date: 24 July I948. Position: $5 \mathrm{I}^{\circ} 36 \cdot \mathrm{I}^{\prime} \mathrm{N} ., 02^{\circ} 4 \mathrm{I} \cdot 2^{\prime} \mathrm{E}$. Conditions: excellent, hazy atmosphere, no direct sunlight, oily sea, slight swell. Secchi disk: $13 \frac{1}{2} \mathrm{~m}$.

\begin{tabular}{|c|c|c|c|c|c|}
\hline \multirow{3}{*}{$\begin{array}{c}\text { Depth } \\
\text { (m.) }\end{array}$} & \multicolumn{5}{|c|}{ Photoelectric measurements } \\
\hline & \multicolumn{2}{|c|}{ Transmission ratio (\%) } & \multicolumn{3}{|c|}{ Temperature ( ${ }^{\circ} \mathrm{C}$.) } \\
\hline & Down & Up & Resistance & Temp. (R) & Temp. (Hg) \\
\hline 0 & $97 \cdot 5$ & $96 \cdot 5$ & $7 \cdot 58$ & I5.93 & I5:5 \\
\hline I & 79.5 & 78.8 & - & - & - \\
\hline 2 & 69.5 & $70 \cdot 0$ & - & - & - \\
\hline 3 & $61 \cdot 7$ & $60 \cdot 5$ & - & - & - \\
\hline 4 & $54{ }^{\circ}$ & $5 \mathrm{r} \cdot 2$ & - & 一 & - \\
\hline 5 & $47 \cdot 8$ & $45 \cdot 5$ & $7 \cdot 53$ & I5.79 & - \\
\hline 6 & $44^{\circ} 0$ & $42 \cdot 0$ & - & - & - \\
\hline 7 & $4 I \cdot 25$ & 38.0 * & - & - & - \\
\hline 8 & 37.0 & $35 \cdot 5^{\star}$ & - & - & - \\
\hline 9 & 34.0 & $32 \cdot 5$ & - & - & - \\
\hline IO & $3 I \cdot 25$ & 29.5 & $7 \cdot 52$ & I5.76 & - \\
\hline II & $27.0^{\circ}$ & 28.0 & - & - & - \\
\hline I2 & 24.0 & $25 \cdot 5$ & - & - & - \\
\hline I3 & $22 \cdot 0$ & 23.0 & - & - & - \\
\hline 14 & $20 \cdot 0$ & $2 \mathrm{I} \cdot \mathrm{O}^{\star}$ & - & - & - \\
\hline I5 & I8.8 & $19 \cdot 2^{\star}$ & $7 \cdot 52$ & $15 \cdot 76$ & - \\
\hline เ6 & I7.4 & $I 7 \cdot 4$ & - & - & - \\
\hline 17 & 16.5 & 16.8 & - & - & - \\
\hline I8 & 15.5 & 15.0 & - & - & - \\
\hline 27 & $6 \cdot 2$ & - & $7 \cdot 50$ & I5.7I & - \\
\hline
\end{tabular}

From graph:

$$
\text { Calculation of extinction coefficients }
$$

$$
\begin{aligned}
& P_{5}=\frac{2 \cdot 3(\log 72-\log 30)}{\text { IO }}=0.23(\mathrm{I} \cdot 875-\mathrm{I} \cdot 478)=0.0875, \\
& P_{1}=\frac{2.3(\log 30-\log \mathrm{I} 2)}{\text { IO }}=0.23(\mathrm{I} \cdot 478-\mathrm{I} \cdot 080)=0.0915 .
\end{aligned}
$$




\section{STATION No. 9}

Time: Ir.00 G.M.t. Date: 25 July 1948. Position: $5 \mathrm{I}^{\circ} \mathrm{I2}^{\prime}$ N., or $^{\circ} 54^{\prime}$ E. Sea depth: I5 fathoms.

Conditions: very fine, bright sun, horizon hazy, light breeze, slight swell, negligible sea, wind went flat calm during photoelectric experiments, ship rolling.

Secchi disk: $\mathrm{I} \mathrm{I} \frac{1}{2} \mathrm{~m}$.

\begin{tabular}{|c|c|c|c|c|}
\hline \multirow{3}{*}{$\begin{array}{l}\text { Depth } \\
\text { (m.) }\end{array}$} & \multicolumn{3}{|c|}{ Photoelectric measurements } & ${ }^{\text {nents }}$ Temperature $\left({ }^{\circ} \mathrm{C}.\right)$ \\
\hline & \multicolumn{2}{|c|}{ Transmission ratio (\%) } & Resistance & Check $(\mathrm{Hg})$ \\
\hline & Down & Up & thermometer & temp. \\
\hline$\circ$ & 94 & 100 & $15 \cdot 5$ & I5.5 \\
\hline I & $87 \cdot 5$ & 90 & - & \\
\hline 2 & 75 & $79 \cdot 5$ & $\bar{z}$ & - \\
\hline 3 & & 71 & $\bar{z}$ & 二 \\
\hline 4 & $\begin{array}{l}6 \mathrm{I} \\
52\end{array}$ & $\begin{array}{l}66 \\
58\end{array}$ & 二 & $\bar{z}$ \\
\hline $\begin{array}{l}5 \\
6\end{array}$ & $\begin{array}{l}52 \\
49\end{array}$ & $\begin{array}{l}58 \\
56 \cdot 5\end{array}$ & I6. I & 二 \\
\hline 7 & 44 & $52 \cdot 5$ & - & - \\
\hline 8 & 39 & $42 \cdot 5$ & - & - \\
\hline 9 & $3 \mathrm{I}$ & $37 \cdot 5$ & - & - \\
\hline Io & $30 \cdot 5$ & 35.5 & - & \\
\hline II & 25 & 28.3 & - & - \\
\hline I2 & $2 \mathrm{I}$ & $25 \cdot 2$ & - & - \\
\hline I3 & I9.5 & $22 \cdot 5$ & - & - \\
\hline I4 & 17.0 & 19.5 & - & - \\
\hline 15 & 15.4 & 17.5 & I6. I & - \\
\hline 16 & $13 \cdot 2$ & 15.5 & - & - \\
\hline I7 & $12 \cdot 0$ & 14 & - & - \\
\hline 18 & & 13 & - & - \\
\hline $26 \cdot 5$ & $3 \cdot 5$ & & - & - \\
\hline
\end{tabular}

Note. Bright sun would be expected to fatigue deck cell and cause sea cell to appear more sensitive on upward path. Readings of opacity support this.

Extinction coefficients (calculated as above): $P_{5}=0.101 . \quad P_{15}=0.124$.

\section{Station No. I2}

Time: 07.30 G.M.T. Date: 30 July 1948 . Position: $5 \mathrm{I}^{\circ} \mathrm{II} \cdot 5^{\prime} \mathrm{N} ., 02^{\circ} 4 \mathrm{I} \cdot 5^{\prime} \mathrm{E}$.

Conditions: weather fine, bright sunlight, very hazy, horizon visibility I mile, wind force I north, very slight sea and swell.

Secchi disk: $5^{\frac{1}{2}} \mathrm{~m}$.

Photoelectric measurements

\begin{tabular}{|c|c|c|c|c|c|}
\hline \multirow{2}{*}{$\begin{array}{l}\text { Depth } \\
\text { (m.) }\end{array}$} & \multicolumn{2}{|c|}{ Transmission ratio ( $\%)$} & \multicolumn{3}{|c|}{ Temperature $\left({ }^{\circ} \mathrm{C}.\right)$} \\
\hline & Down & Up & Resistance & Temp. (R) & Temp. (Hg) \\
\hline o & $9 \mathrm{I}$ & IOO & $8 \cdot 49$ & I8.37 & I 8.0 \\
\hline I & $76 \cdot 5$ & $75 \cdot 0$ & $8 \cdot 48$ & $18 \cdot 35$ & - \\
\hline 2 & $60 \cdot 0$ & $59 \cdot 0$ & $8 \cdot 47$ & $18 \cdot 32$ & - \\
\hline 3 & $45^{\circ} 0$ & $43 \cdot 5$ & $8 \cdot 47$ & $18 \cdot 32$ & - \\
\hline 4 & $3 \mathrm{I} \cdot 5$ & 28.0 & $8 \cdot 47$ & $18 \cdot 32$ & - \\
\hline 5 & $22 \cdot 0$ & $20 \cdot 0$ & $8 \cdot 46$ & $18 \cdot 29$ & - \\
\hline 6 & $16 \cdot 0$ & 14.5 & $8 \cdot 46$ & $18 \cdot 29$ & - \\
\hline 7 & $\mathrm{II} \cdot 5$ & 10.5 & $8 \cdot 45$ & 18.27 & - \\
\hline 8 & $8 \cdot 5$ & $7 \cdot 5$ & 8.45 & I8.27 & - \\
\hline 9 & $6 \cdot 5$ & $6 \cdot 5$ & 8.45 & 18.27 & - \\
\hline Io & $4 \cdot 34$ & $4 \cdot 04$ & $8 \cdot 45$ & $18 \cdot 27$ & - \\
\hline II & 2.94 & 2.80 & - & - & - \\
\hline I2 & $2 \cdot 13$ & 2.02 & - & - & - \\
\hline I3 & $\mathrm{I} \cdot 08$ & - & $8 \cdot 44$ & I $8 \cdot 24$ & - \\
\hline
\end{tabular}




\section{STATION No. 23}

Time: 15.45 G.M.t. Date: 24 August 1948. Position: 24 miles south of Portland Bill, $50^{\circ} 07 \cdot 5^{\prime} \mathrm{N} ., 02^{\circ} 2 \mathrm{I}^{\prime} 5^{\prime} \mathrm{W}$.

Conditions: misty, drizzle, sea ruffled, small waves, measurements easy, Galvo spot steady.

Secchi disk: $13.0 \mathrm{~m}$.

Photoelectric measurements

\begin{tabular}{|c|c|c|}
\hline \multirow{2}{*}{$\begin{array}{l}\text { Depth } \\
\text { (m.) }\end{array}$} & \multicolumn{2}{|c|}{ Transmission ratio (\%) } \\
\hline & Down & Up \\
\hline 0 & $105 \cdot 5$ & IO3 \\
\hline I & 82 & 80 \\
\hline 2 & 70 & 69 \\
\hline 3 & 59.5 & 59 \\
\hline 4 & $52 \cdot 0$ & 53 \\
\hline 5 & $48 \cdot 0$ & 49 \\
\hline 6 & 44 & 43.5 \\
\hline 7 & 39 & 38 \\
\hline 8 & $35 \cdot 8$ & 37.5 \\
\hline 9 & 33 & 33 \\
\hline IO & $3 I$ & $3 I$ \\
\hline
\end{tabular}

$\begin{gathered}\text { Depth } \\ \text { (m.) }\end{gathered}$
II
I2
I3
I4
I5
I6
I7
I8
23
26

\begin{tabular}{ll} 
Down & \multicolumn{1}{c}{ Up } \\
$28 \cdot 2$ & $30 \cdot 5$ \\
26 & $26 \cdot 2$ \\
$23 \cdot 8$ & 24 \\
$21 \cdot 8$ & $2 \mathrm{I} \cdot 0$ \\
20.5 & 20 \\
$\mathrm{I} 8$ & $\mathrm{I} 8.8$ \\
$\mathrm{I} 7$ & $\mathrm{I} 8$ \\
$\mathrm{I} 6 \cdot 2$ & $\mathrm{I} 7$ \\
8.8 & - \\
7.5 & -
\end{tabular}

Extinction coefficients (calculated as above)

$$
P_{5}=0.0842 \text {. } \quad P_{15}=0.0792 \text {. }
$$

\section{Station No. E I}

Time: I4.00 G.M.T. Date: 6 September 1948. Position: $50^{\circ} 04^{\prime}$ N., $04^{\circ} 22^{\prime}$ N.

Conditions: very bad, sun casting awkward shadows, too much wind, ship never stationary, continually turning and rolling.

Secchi disk: $9.0 \mathrm{~m}$. before experiments; $8.5 \mathrm{~min}$. after experiments, at I5.45 G.M.T.

Photocells: initial comparison on deck, IO5\%; cell ready to lower, IOI.5; deck cell also wet, I04; deck cell dry, IOr.

\section{Photoelectric measurements}

\begin{tabular}{|c|c|c|c|c|c|c|}
\hline \multirow{2}{*}{$\begin{array}{c}\text { Depth } \\
\text { (m.) }\end{array}$} & \multicolumn{4}{|c|}{ Transmission ratio (\%) } & & \\
\hline & Down & Up & \multicolumn{4}{|c|}{ Checks } \\
\hline 0 & IOI & I03 & - & - & - & 一 \\
\hline I & 75 & 80 & 84 & - & - & - \\
\hline 2 & 67 & 69 & - & 一 & - & - \\
\hline 3 & 60 & $54 \cdot 5$ & $53 \cdot 8$ & $5 \mathrm{I}$ & 55 & - \\
\hline 4 & 50 & 44 & $42 \cdot 5$ & $4 \mathrm{I}$ & 42 & - \\
\hline 5 & $45 \cdot 5$ & $35 \cdot 5$ & $35 \cdot 5$ & 36 & 35 & - \\
\hline 6 & 34.5 & 28 & 29 & - & - & - \\
\hline 7 & 30.5 & $26 \cdot 0$ & 25.5 & 25 & - & - \\
\hline 8 & $27^{\circ} 0$ & 22.5 & 23.5 & - & - & - \\
\hline 9 & 25.0 & $2 \mathrm{I} \cdot \mathrm{O}$ & 19.5 & I8 & - & - \\
\hline IO & 20.5 & 19.0 & $17 \cdot 8$ & 17 & I7 & 18.5 \\
\hline II & 18.0 & I6.8 & 16.5 & - & - & - \\
\hline I2 & 15.0 & I 4.0 & $150^{\circ}$ & - & - & - \\
\hline I3 & 13.0 & 13.0 & 13.0 & - & - & - \\
\hline I 4 & 13.0 & II.O & II. 5 & - & - & - \\
\hline I5 & 10.5 & 10.5 & - & - & - & - \\
\hline I6 & $8 \cdot 5$ & 8.8 & 8.5 & - & - & - \\
\hline I7 & $7 \cdot 5$ & $8 \cdot 5$ & $8 \cdot 0^{\circ}$ & 一 & - & - \\
\hline 18 & $7 \cdot 5$ & 8.5 & $5 \cdot 5$ & - & - & - \\
\hline $26 \frac{1}{2}$ & 30 & - & - & - & - & - \\
\hline
\end{tabular}

Extinction coefficients (calculated as above)

$$
P_{5}=0.1225 . \quad P_{15}=0.1220 .
$$


Station No. 24

Time: 10.40 G.M.T. Date: 9 September 1948. Position: north-east end of race of Alderney. $49^{\circ} 47 \cdot 5^{\prime} \mathrm{N} ., \mathrm{O}^{\circ} \mathrm{OI} \cdot \mathrm{O}^{\prime} \mathrm{W}$. drifting north-east.

Conditions: sea very turbulent, wind light, bright sun.

Secchi disk: $7 \frac{1}{4} \mathrm{~m}$.

\begin{tabular}{|c|c|c|}
\hline \multirow{2}{*}{$\begin{array}{c}\text { Depth } \\
\text { (m.) }\end{array}$} & \multicolumn{2}{|c|}{ Transmission ratio $(\%)$} \\
\hline & Down & Up \\
\hline 0 & 97 & IOO \\
\hline I & 84 & 82 \\
\hline 2 & 63 & 65.5 \\
\hline 3 & $52 \cdot 5$ & 52 \\
\hline 4 & 45 & 45 \\
\hline 5 & $34 \cdot 5$ & 35 \\
\hline 6 & 27 & 28 \\
\hline 7 & 20 & $2 \mathrm{I}$ \\
\hline 8 & I7 & I7 \\
\hline 9 & 12.5 & 13 \\
\hline I0 & II & II 5 \\
\hline II & 9 & 9.8 \\
\hline I2 & $7 \cdot 5$ & $7 \cdot 7$ \\
\hline I3 & 5.5 & 6.0 \\
\hline I4 & $4 \cdot 2$ & $4 \cdot 8$ \\
\hline 15 & 3.5 & $4 \cdot I 7$ \\
\hline I6 & $3 \cdot 2$ & $3 \cdot 3 \mathrm{I}$ \\
\hline I7 & 3.0 & $2 \cdot 37$ \\
\hline I8 & $2 \cdot 5$ & $I \cdot 805$ \\
\hline 26 & - & 0.322 \\
\hline
\end{tabular}

Turbulence less noticeable on 'up' path. Turbulence most noticeable at 4 and $5 \mathrm{~m}$.

Extinction coefficients (calculated as above)

$P_{5}=0.215 . \quad P_{15}=0.208$. 


\section{II}

The transmission ratio at depths at which the Secchi disk disappears under different weather conditions.

Readings were extracted from Table II as follows:

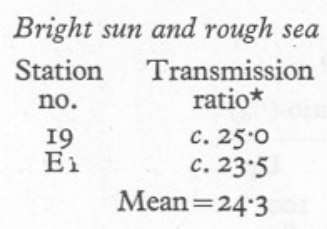

No sun and rough sea

Station Transmission

no. ratio ${ }^{\star}$

E I $23 \cdot 5$

$23 \quad 23.9$

I9 $25 \cdot 0$

All 'rough sea' stations $(\mathrm{I} 9,23, \mathrm{E} \mathrm{r})$

Mean $24 \cdot I( \pm c . \mathrm{I} \cdot 7)$
Bright sun and calm sea

\begin{tabular}{|c|c|c|}
\hline $\begin{array}{l}\text { Station } \\
\text { no. }\end{array}$ & $\begin{array}{c}\text { Transmission } \\
\text { ratio* }^{\star}\end{array}$ & Deviation* \\
\hline I & $c .2 \mathrm{I} \cdot 5$ & c. $+\mathrm{I} \cdot \mathrm{I}$ \\
\hline & c. $24 \cdot 5$ & $+3 \cdot I$ \\
\hline Io & $23 \cdot 0$ & $+2 \cdot 6$ \\
\hline II & I6. I & $-4 \cdot 3$ \\
\hline $\mathrm{I} 2$ & I8.7 & $\begin{array}{r}-1.7 \\
-1.7\end{array}$ \\
\hline $2 \mathrm{I}$ & 20.0 & -0.4 \\
\hline 24 & $19 \cdot 2$ & $-1 \cdot 2$ \\
\hline \multicolumn{2}{|c|}{$\begin{array}{r}\text { Mean }=20.43 \\
\sigma=2.83\end{array}$} & $\begin{array}{c}\sigma_{m}=\mathrm{I} \cdot 07 \\
0\end{array}$ \\
\hline
\end{tabular}

No sun and calm sea

\begin{tabular}{|c|c|c|}
\hline $\begin{array}{l}\text { Station } \\
\text { no. }\end{array}$ & $\begin{array}{c}\text { Transmission } \\
\text { ratio }^{\star}\end{array}$ & Deviation* \\
\hline 8 & $2 I \cdot 5$ & $c .+2 \cdot 7$ \\
\hline I8 & $17 \cdot 3$ & $-\mathrm{r} \cdot 5$ \\
\hline I4 & I7.0 & $-\mathrm{I} \cdot 8$ \\
\hline 21 & 20.0 & $+\mathrm{I} \cdot 2$ \\
\hline 22 & 18.0 & -0.8 \\
\hline & $\begin{aligned} \text { an } & =\mathrm{I} 8.8 \\
\sigma & =\mathrm{I} \cdot 92\end{aligned}$ & $\sigma_{m}=\overline{0.86}$ \\
\hline
\end{tabular}

All 'calm sea' stations

(I, 8, 9, IO, II, I2, I4, I8, 2I, 22, 24)

Mean $19 \cdot 7 \pm 0.80$

$\begin{array}{ll}\sigma & 2.66\end{array}$

* Current ratio at Secchi disk depth. 